\title{
Dracula's image in tourism: Western bloggers versus tour guides
}

\author{
Maria Banyai $^{{ }^{1 *}}$
}

Received: 24/09/2009 Accepted: 06/12/2009

\footnotetext{
${ }^{1}$ Department of Recreation and Leisure Studies, Faculty of Applied Health Sciences, University of Waterloo, 200 University Avenue West, Waterloo, Ontario, Canada N2L 3G1; phone: 1-519-8884567, ext. 33894, e-mail: mbanyai@uwaterloo.ca

* Corresponding author
}

\begin{abstract}
This study attempted to describe the different Western images related to Dracula tourism, and the role Bran Castle tour guides have in the image formation process. This is accomplished by analyzing the contents of Western tourists' travel blogs, and of qualitative interviews elicited from Bran Castle tour guides. The qualitative content analysis resulted in seven themes focused on historical and fictional images of the destination. The results show that the majority of Western bloggers visit Bran in search for Count Dracula; however, the Bran Castle tour guides focus on presenting the historical truth. The findings are discussed in terms of their relevance to the destination image formation literature and the concept of authenticity.
\end{abstract}

(C) 2010 International University College. All rights reserved

Keywords: destination image, literary tourism, authenticity, Dracula

Citation: Banyai, M. (2010) Dracula's image in tourism: Western bloggers versus tour guides. European Journal of Tourism Research 3(1), pp. 5-22

\section{Introduction}

The value of the destination image to the local destination marketing organizations and other destination promoters is incontestable due to its power to attract more tourists to the area. Fakeye and Crompton (1991) note that images are of paramount importance to destinations because they have the power to change and rearrange the tourists' impressions and perceptions of a destination and "give him or her a pre-taste of the destination" (p. 10). The traveller's image of a destination is built not only on past experiences and marketing communications, but also on non-promotional media such as films, novels and television shows.

Squire (1996) notes that literary tourism - a form of tourism inspired by novels and poetry "is premised upon the public's desire to experience a version of the past (or imagined present) and to make connections between past and present, fact and fiction. It, therefore, trades in images and expectations of people, places and particular historic periods" (p. 129). The image of a destination can therefore be based on images being portrayed in movies and novels, but also on the tourists' interpretation of these images and their 
expectations of these images to be seen at the destination.

The destination images held by consumers are so powerful that they can either benefit the country or have a negative impact. In order to benefit the destination, images have to be distinctive, appealing, simple, and most importantly, believable and should be based on reality (Kotler and Gertner 2004). However, because authenticity is a widely subjective concept, any image can be perceived as authentic depending on whom the viewer is.

The main objectives of this study are to analyse destination images related to Dracula tourism as portrayed by Western tourists on their Internet blogs, and to explore how tour guides working at Bran Castle have responded to these images.

The paper is divided into seven sections. After an introduction to Dracula tourism in section two, section three includes an overview of the destination image, literary tourism and authenticity literature. Section four describes the research and analysis methods, while section five presents the findings. Section six involves a discussion of the findings as they relate to the literature review and section seven presents the conclusions of the study and possibilities for future research.

\section{Contextual setting}

Historical, literary and film background

In Western culture, Transylvania has long been a place of profound images related to vampires and dark forces. These images have resulted in the portrayal of a beautiful Romanian region as one of the most sinister and mysterious regions in Europe: Transylvania, the land of Dracula. As supernatural as some might think Dracula is, he was a real person - a ruler in Wallachia, now a province of Romania called Muntenia. Born circa 1430 in Sighisoara, Romania, Vlad Tepes was the son of Vlad Dracul, the ruler of Wallachia (Newman, 2004). Acts of brutality against Turkish invaders and boyars have been used by Dracula in an attempt to keep traitors away and discourage the Ottoman Empire to fight over his territory. Dracula's massive killings were not necessarily what shocked the society; "he gained notoriety for his exceptionally harsh rule and his practice of impaling both lawbreakers and his Ottoman enemies on wooden stakes" (Light, 2007, p. 750).

However, a novel written in the 19th century would change the historical figure into a mythical vampire. Bram Stoker's novel, written in 1897 in London, England portrays a Victorian vampire able to keep itself immortal by drinking the blood of humans (Ronay, 1972). Stoker gives his character a Transylvanian identity and endows him with vampire like characteristic such as "pointed ears and protruding canine....coarse, broad hands with squat fingers - as werewolves are described. His palms, too, are hairy and the nails cut to a sharp point. His eyes glow red" (Leatherdale, 1987, p. 105).

The film industry has also played an important role into the creation and promotion of mythical Count Dracula. "Universal had made several Dracula movies with Bela Lugosi between 1930 and 1960. Bypassing all real historical prototypes and Stoker's character, Universal now claimed it had in fact developed and respectively patented Dracula's image with the black cape, the deathly pale skin, and the fangs" (Iordanova, 2007, p. 56). The Hollywood-style Dracula began to grow in postcommunist Romania only in 1992 when the movie Bram Stoker's Dracula, directed by Francis Ford Coppola, was released to Romanian viewers (Iordanova, 2007). The historical Vlad Tepes has undergone many changes throughout the decades, and sadly his image changed from that of a hero to a vampire thirsty for human blood. Nevertheless, today, "Romanians are most likely to regard Vlad Tepes as a national hero who fought against the Turks and freed the country from the rule of the Ottoman Empire" (Muresan and Smith, 1998, p. 76).

\section{Dracula tourism}

In 2006, more than 6 million international tourists visited Romania, of which over 1 million stayed overnight at various types of accommodations (National Institute of Statistics, 2007). While Dracula tourism data is 
not gathered by the Romanian National Institute of Statistics, researchers note that Dracula tourism attracts about 250,000 tourists annually (Jamal and Tanase, 2005, Iordanova, 2007).

Muresan and Smith (1998) categorize Dracula tourism as a form of literary and film tourism in which tourists desire to see the places connected to a novel or a writer and to search a reality based on fiction. Tourists travel to Transylvania in hopes to discover the real landscapes described by Stoker and the surroundings where the themes of more than 1000 vampirism novels take place (Light, 2007). Early Dracula enthusiasts who travelled to Transylvania "found little to cater to their interests, not because of hostility from the socialist authorities but simply because the Western Dracula myth was virtually unknown to Romania" (Light, 2007, p. 753). Just about over a decade ago the majority of ordinary Romanians, and particularly the inhabitants of Transylvania, were unaware of the international infamy of Vlad the Impaler and his literary counterpart, the chilling Count Dracula (lordanova, 2007). However, after the 1989 Revolution, post-communist Romania emerged as a global marketplace in which tourism has been identified as one means for establishing a new national identity and for establishing competitive advantage in the regional and international economy (Jamal and Tanase, 2007).

Despite never being the residence of Vlad Tepes, due to the demand and increase in international tourists to Transylvania in search of Dracula, the Romanian Ministry of Tourism has promoted Bran Castle as Dracula's Castle for a number of reasons: its accessibility and location near the town of Brasov - the second largest tourist destination in Romania, and its medieval look which falls along the descriptions of Count Dracula's castle (Muresan and Smith, 1998). The tourists visiting the castle have been so far exposed to two different marketing strategies: the tourism agencies' fictionoriented approach and the Government's factoriented policy (Light, 2007). However, the recent restitution of Bran Castle to the
Habsburg regal family might change the way Dracula is being promoted. The May 2006 legal retrocession followed by the verbal agreement on May 19, 2009, returns the castle to Archduke Dominic Habsburg-Lothringen, the son of Princess lleana of Romania (Dan, 2009). This development offers the new owner an open gate to promoting Bran Castle to the world. Whether he decides to promote the historical nature of the castle, or the mythical vampire, it is unknown. No matter what the future entails, Transylvania as a destination does not lack fame.

Transylvania's image has been further influenced by the proposal made by the Romanian Ministry of Tourism to develop a Dracula theme park in Transylvania (Iordanova, 2007, Light 2007, Jamal and Tanase, 2005). After deliberations and consultation with PricewaterhouseCoopers in 2002, the project which has been estimated to cost $\$ 31.4$ million was doomed unfeasible due to "serious doubts as to the park's chance to offer something that would not already be available at more accessible locations in the West and that would prompt masses of Western tourist to take the trip to Romania" (Iordanova, 2007, p. 52). However, maybe the biggest realization of this project was that even if Dracula is marketable, there is no existing demand for the product within Romania's domestic market (Iordanova, 2007, Muresan and Smith, 1998).

\section{Literature review}

\section{Defining destination image}

Oftentimes tourists make travel decisions based on how they sense, understand, use and connect to the place (Kavaratzis and Ashworth, 2004). Because there is no single, accepted definition for "destination image", San Martin and del Bosque (2008) compiled a table to show the main similarities among definitions from 1977 to 2003. Most of the definitions include terms such as "impression" and "perception" of tourists to describe the concept of destination image. The repetition of these terms reinforces the idea that the tourists are ultimately the ones who influence the way a destination is viewed by the world. Based on their personal impressions and perceptions, 
tourists have the power to influence the tourism flow to any destination. San Martin and del Bosque (2008), in their explanation of how destination images are formed, note that the consumers' perception of a destination is based on information from different sources over time, which is selected, elaborated and embellished in order to have a meaningful existence. The information involved in image formation can include promotion materials, the opinions of family and friends, media reports but also popular culture which includes novels and movies (Govers, Go and Kumar, 2007). To better understand how these images are formed, a brief summary of image formation literature is necessary.

\section{Image formation}

Image formation involves the creation of images about a destination based on information selected by a person from various image formation agents (Tasci and Gartner, 2007). Tasci and Gartner (2007) believe that the process of image formation involves three main agents: (1) supply-side, (2) independent, and (3) demand-side. The supply side is often identified as information promoted by the destination, while the demand side represents tourists' expectations. The two sides of destination image formation process have been identified by Baloglu and McCleary (1999) as the personal and stimulus factors. The interactive relationship between the destination image and various factors described in their framework results in an image constructed on tourists' impression and perception of the destination as influenced by their cultural background and the information sources they come into contact with.

Tourists form their impressions and perceptions of the destination based on manifest components such as the price of the vacation and the spatial picture, but also on latent elements of the destination such as the friendliness of staff or overall feeling of the destination. To address the multidimensionality of elements involved in the creation of destination images, Echtner and Ritchie (1991) created a framework based on three different sets of components required in the destination image formation process:
1. attribute-holistic set - comprised of those perceptions of individual attributes and the more holistic impressions of place;

2. functional-psychological set - compri-sed of elements that are observable and measurable and those that are less tangible;

3. common-unique set - comprised of the destination images ranging from common to unique.

Although the model appears to divide the concept of image into three different and independent components, there is overlap among the three. For example, "holistic impressions are based on combinations and interactions of attributes and, in turn, perceptions of individual attributes may be influenced by overall impressions and feelings" (Echtner and Ritchie, 1991, p. 5).

While the above frameworks try to conceptualize the process of destination image formation, Govers, Go and Kumar (2007) argue that previous studies are static in nature, concentrating on the relationship between destination image and a variety of agents. To identify those elements that have a dynamic role in the formation of destination images, Govers, Go and Kumar developed the 3-Gap Tourism Destination Image Formation Model based on the deconstruction of the destination image formation process. The framework allows for the inclusion of the local tourism industry and the marketing mix used in promoting the destination as dynamic factors in the creation of the destination image. It is when the tourism product is not aligned with the destination image projected, or when tourists' expectations are not met either due to their unrealistic demand or failure of the destination to deliver projected promises, that several gaps appear in the image formation process: the tourism development strategy gap, the tourism delivery and supply gap, and the tourist demands specifications gap. By addressing these gaps, tourism destinations can balance the promotion of the destination image with tourists' expectations and demands. The next section will discuss the case of literary tourism, a form of tourism where destination images are built on literary works but also on tourists' 
expectations of what they would find at the destination.

\section{Literary tourism}

Tourism destinations which are associated with a famous novel are popular sites because they offer travelers the opportunity to emerge themselves in imagined places associated with fictional characters (Squire 1994, 1996; Herbert 1996, 2001). The meanings tourists give to literary sites are real to the "beholder" because they are created with the fictional world in mind, allowing tourists to be less concerned with the distinction between fiction and reality (Herbert, 2001). Novels offer tourists "a certain lens through which reality is depicted, as well as the opportunity to participate in the fictionalized experience" (McCabe 1998, p.236). It is the perceptions of tourists that create the surreal land that they experience along with the objective elements of the destination such as the houses, natural environment and other artifacts. Because of the effect these sites have on tourists, "literary places are no longer accidents of history, sites of a writer's birth or death; they are also social constructions, created, amplified, and promoted to attract visitors" (Herbert 2001, p.313).

The process of image-building starts from the involvement of those implicated in production, followed by a stage of enriching experiences through presentation texts which are then used by visitors to give meaning to a site (Herbert, 1996). Within this process, Squire (1994) argues that the real places and the promotional material act as "a medium through which a range of cultural meanings and values can be communicated" (p.104). Furthermore, Reisinger and Steiner (2006) note that tour guides have an important role on how tourists think and feel with respect to the destination because they have direct contact with tourists and are able to influence their impressions and perceptions through various interpretive materials. The nature of the material presented also influences the perceived authenticity of the destination. Because literary tourism sites are often constructed on both realistic and imaginary elements, for example 'Anne of Green Gables' attractions in PEI, Canada, and Beatrix Potter's Peter Rabbit attractions in the
Lake District Park, England; it is important to discuss the difference between the objective and the subjective authenticity of tourism destinations.

\section{Destination image authenticity}

Although the concept of authenticity has been of interest for many years, researchers still have a hard time defining the concept (Pearce and Moscado, 1986; Cohen, 1988, Taylor, 2001, Reisinger and Steiner, 2006, McCannell, 1973, 1976, Pine and Gilmore, 2008). Reisinger and Steiner (2006) note that in most studies "the intent is to find a way to stabilize how authenticity is defined and applied in tourism and to lay the groundwork for negotiations within the field on its meaning and significance" (p. 66). Authenticity is a concept which can be either subjectively or objectively viewed. This allows researchers to be more flexible when assessing the authenticity of a destination or attraction; however, it also raises concerns of consistency and validity in research.

From an objectivist perspective, authenticity is a concept that pays "homage to a conception of the original" (Taylor, 2001, p.9). This original, in relation to ancient art, monuments and objects, has usually been understood as the material integrity of the object itself which cannot be debatable (Holtorf and Schadla-Hall, 1999, Reisinger and Steiner, 2006). The authenticity of a place, object, or tradition is viewed by objectivists as being genuine, actual, accurate, original and true. Any element, in the objectivist view, "has the flavour of realism, which is based on the ideas that there is an objectively real world to which one can refer as a standard or for confirmation when making judgments about what is true, genuine, accurate or authentic" (Reisinger and Steiner, 2006. p. 69).

However, Pearce and Moscardo (1986) argue that "authenticity can be achieved either through environmental experiences, peoplebased experiences, or a joint interaction of these elements" (p. 125). The authenticity of a destination can be created by the tourists themselves due to their own beliefs, expectations, preferences, and stereotyped 
images, but it can also be influenced by tour guides who can influence the tourists' impressions and perceptions of the destination (Reisinger and Steiner, 2006). Endensor (2001) notes that tourists perform "diverse meanings about the symbolic places, dramatizing their allegiance to places and kinds of actions" ( $p$. 71). Therefore, the authenticity of a destination can be affected by the tourists' impressions and images of the destination, images that could be built on traditional forms of media and pop culture, but also on the information provided at the destination.

The various factors involved in creating destination images have been discussed herein as part of the larger bodies of literature including destination image, literary tourism and the concept of authenticity. These sensitizing concepts provide valuable insight into how destination images are formed, especially within a literary tourism realm, but also how tourists perceive the authenticity of these images.

\section{Methodology}

Research goal and questions

The goal of this study is to describe various images related to Dracula tourism in Transylvania as expressed by Western tourists on personal web logs, and to explore the role of Bran Castle tour guides in the process of image formation. The research questions guiding this study were: (1) What are the Western images associated with Dracula tourism?; and (2) What Dracula images are being promoted at Bran Castle? The exploratory nature of the questions allowed the researcher to investigate the various Western images related to Dracula tourism and to stay open to the information provided by bloggers and Bran Castle tour guides about their experiences.

Data sample, collection procedure and instrument

The two study populations in this research were the tour guides working at Bran Castle, and the Western tourists who have visited Bran Castle and documented their experiences on Internet blogs. The size of the sample used was three tour guides (there were 5 tour guides employed at Bran Castle museum at the time of the research), and 20 Internet blogs written by British and American tourists.

The data was collected in the spring of 2009. The tour guides were all females, and have worked as tour guides at Bran Castle for about 10 years. After the initial contact when tour guides were informed of the study and asked for their willingness to participate, the researcher contacted them via telephone at a mutually agreed day and time to conduct the interviews. The tour guides were interviewed through the use of an in-depth semi-structured interview. Patton (2002) notes that, when doing qualitative research, it is important to use openended questions because they are "longer, more detailed, and variable in content" (p.20), but more importantly, they allow the researcher and the readers to see the world through the eyes of the respondents. The interview focused on the tour guides' experiences and practices, and on the Western tourists' demands and expectations while visiting the castle.

The 20 blogs selected for analysis were selected through search engines such as Google and Yahoo, using the following search terms: "Dracula", "Bran Castle", and "Transylvania". The blogs were initially screened to identify if the blogger was a Western tourist and if the content was a result of visitation. If the blogger did not mention his/her nationality, or if the blog did not reflect visitation at Bran Castle but simply opinion statements or Dracula related presentations, it was excluded from the sample. This process resulted in the exclusion of the majority of search results, hence the 20 blogs sample. Text, photo and video blogs were selected to obtain richer data about Westerners' image of Dracula. While text blogs are often rich in manifest meanings, the latent meanings are often better extrapolated from videos and photographs where bloggers' have the opportunity to convey vocal and facial expressions.

The Western bloggers included ten male, four female, and six group bloggers such as families, friends or couples. Out of the 20 blogs selected, 14 blogs were text and picture blogs, and six were video blogs. Half of the text and 
picture blogs were found on Blogger - a renowned blogging site - while the other half were posted on personal websites. The video blogs were generally found on You Tube - a video sharing site - but also on a similar website called Metacafe. The blogs were chronologically ordered, starting with the most recent. They range from January 2007 to March 2009. 15 blogs were published by Americans and five blogs by British bloggers.

\section{Analysis strategy}

The exploratory nature of the research questions followed an interpretive approach to research, where the researcher is involved in creating meaning based on the interaction with those under research and past experiences and knowledge (Daly, 2007). Interpretivism is rooted in the belief that reality is co-constructed between the researcher and those under research. Therefore, research often involves a subjective meaning-making process, where the researcher constructs meaning based on "the internal processes of the mind and the externally available processes of the social world" (Daly, 2007, p. 32). This results in the ability to represent the reality under research in multiple ways.

Qualitative content analysis was used to categorize both the manifest and latent meanings into themes. Krippendorff (2004) notes that, in qualitative research, content analysis involves the close reading of relatively small amounts of data; the interpretation of verbal, pictorial, symbolic, and communication data; and the involvement of the researcher with the study of data interpretation.

\section{a. Text analysis}

To extrapolate both latent and manifest meanings in the text data, a method similar to that of grounded theory, but that does not result in the creation of theory, was used. The key process in qualitative analysis involves the construction of categories that reflect the main thematic patterns (Daly, 2007). The first step involved line-by-line coding (Daly, 2007), followed by theoretical coding (Glaser, 1978) which allows the researcher to create themes aimed at addressing the research goal.

\section{b. Photographs analysis}

The photographs posted on Internet blogs were analyzed as a "visual diary". Hesse-Biber and Leavy (2006) note that when photographs are taken by tourists as a means to remember their experiences, the researcher has to interpret what the tourist found interesting, what story he/she wants to tell. Canton and Santos (2008) used bipolar scales to classify photographs taken by students on an international study tour. The depiction scales are developed to capture the themes of the research while categorizing and organizing the codes.

After reviewing all the photographs posted, two bipolar scales were developed: historical/fictional depictions; and tourist/local consumption. The first scale represented pictures of the historical castle versus pictures of the fictional Dracula from movies. The second scale depicted pictures of the tourists' consumption of the myth through the attempt to imitate Dracula or searching for anything scary, versus the locals' consumption of the myth represented by the their eagerness to sell everything Dracula.

\section{c. Video analysis}

A total of six video blogs were used for the analysis. Fields (1988) notes that the process of qualitative content analysis of videos follows an eight step process: unitizing content, transcription, developing and using categories, verbal analysis, vocal and expressive analysis, scene composition analysis, describing interplay of components and explanation. Transcribing the voice-over in the videos was one of the most important steps in analyzing their content because audio data can be fast and easily misunderstood.

The analysis of the verbal data followed the same procedure as the analysis of the textual blogs. Vocal and expressive meaning units were extrapolated by paying attention to the pitch of voice, tempo, and stress, and the facial expressions of the person appearing in each video scene. Included in the vocal analysis was any musical background. The scene composition of the blogs involved not only moving videos but also still pictures in a 
slideshow format. These images were categorized based on the 2 bipolar scales explained above. The final step of the video analysis involved the amalgamation of all audio, vocal, expressive and visual meaning units into more focused codes in order to show the interrelations between the themes.

\section{Findings}

\section{A. Western tourists' blogs}

The analysis of textual, picture and video blogs resulted in 3 themes. Each theme presented below is first defined in order to understand its meaning within the context, and quotes from participants are used to bring the data to life. The quotations are represented by numbers which were assigned to Western blogs based on the order they were found and recorded.

\section{Reality}

The first theme is Reality, referring to any representation of historical or geographical data expressed by the bloggers through their words or pictures posted on their blogs. The Reality theme has three sub-themes: Vlad Tepes, Romanian ruler; Bran Castle historical museum; and Natural beauty of Transylvania.

\subsection{Vlad Tepes, Romanian ruler}

One of the first reality checks that many bloggers felt compelled to explain was that Dracula was an actual person named Vlad Tepes: "a medieval prince named Vlad who impaled thousands of his enemies" (3), "Vlad Tepes is actually a hero to Romanians...known as Dracula as it means son of Dracul" (11) , "he was a very holy man defending his empire and the church against enemies" (13) , "he was called Vlad Dracul", "Vlad the Impaler - the real Dracula" (14), "Vlad Tepes really was though a real person - a hero to Romania" (17). The bloggers' portrayal of the real Vlad Tepes was present in all blog formats from text to video representations of the historic ruler.

\subsection{Bran Castle historical museum}

The bloggers' journey into Reality includes facts about the historical castle: "Bran Castle was built in 1382 by Saxons" (4), "Bran Castle was originally a stronghold built by the Knights of the Teutonic Order" (5) , "Vlad Tepes is unlikely to have every visited Bran Castle and certainly didn't live there" (11) , "in fact he never even so much as slept here" (17) , "it is not Dracula's castle, though he may have visited there" (6). Once they have established the reality that Bran Castle did not belong to Vlad Tepes, the bloggers explain who really inhabited the castle: "Bran Castle...became home of Queen Marie" (14), "This is really the castle of Mary, Queen of Romania, who lived in the $20^{\text {th }}$ century" (17), "people of Brasov gave castle to Queen Maria of Romania who modernized it" (18).

Some bloggers go into even more detail illustrating the interior of the castle, which is now a museum: "The museum inside the castle does not even mention Dracula and instead highlights the possessions of Queen Maria" (1), "there was nothing about Vlad the Impaler in the castle" (10), "with artefact displays, photographs" (6), "displaying art and furniture" (13). The fact that there is no Dracula exhibition inside the museum gives the tourists the historical view of Bran Castle. Surprisingly to some bloggers, the historical reality does not involve anything vampiristic. This is reflected by blogger 1 who notes that "the castle is a very large fort-house at the top of a hill, but it's not the least bit spooky and only tangentially related to Vlad "Dracula" Tepes".

\subsection{Natural beauty of Transylvania}

Lastly, the natural beauty of Transylvania is being portrayed by Western bloggers. When one blogger was asked by one of his readers whether Transylvania was spooky, his answer was: "Far from it. My primary memory of the train ride is of the gentle, undulating hills as we approach the Carpathians" (1). Other bloggers talk about the "scenery and the mountain views were like none l've ever seen" (5), "the view was breathtaking" (2). Hence, the bloggers' notes on their image of Transylvania reflect the natural reality of the place, a reality that does not include dark and spooky places often associated with vampires.

The photograph and video images support the historical reality by showing images of the exterior castle walls, the interior rooms decorated with medieval furniture and other artefacts. These pictures all fall toward the 
"historic" end of the historical/fictional spectrum. It seems that Reality is an image not easily missed by the Western bloggers visiting Bran Castle.

\section{I know who Dracula is!}

The second theme, I know who Dracula is! represents those images created by the Western movies and novels about vampires, media that have influenced Western tourists' beliefs and impressions about Dracula. The theme has three sub-themes: Dracula movies and novels, Beliefs and feelings about Dracula, and Imitating Dracula.

\subsection{Dracula movies and novels}

As noted previously, the fictional representation of Dracula as a vampire was the creation of Bram Stoker in his novel "Dracula". Many bloggers referred to Stoker's novel to clarify that the real Vlad Tepes was at the heart of his inspiration: "the real Dracula - the one who inspired Bram Stoker to write his book" (3), "Vlad Tepes - Bram Stoker's inspiration for Count Dracula" (8), "Bram Stoker wrote the fictional account of Dracula but used the historic figure of Vlad Tepes" (11), "the fifteen century prince of Wallachia, Vlad Tepes, the real inspiration behind Irish novelist Bram Stoker's iconic vampire count" (13). Indeed, Bram Stoker's novel became an icon and created the Draculian culture. His novel became the inspiration of many vampire movies that not only nurtured a vampire culture, but also made the careers of Hollywood actors such as Bela Lugosi and Gary Oldman.

Lugosi's 1931 portrayal of Count Dracula imbedded itself in the minds of Western people. One blogger admits that as a child, he was "marvelling at the old black and white stills of Bela Lugosi" (13). A male blogger (16), while on his visit to Bran Castle, made sure to interpret everything based on recent Dracula movies. He envisioned Van Helsing putting a cross at the entrance of the castle, Jonathan Parker played by Keanu Reeves walking the steps to the castle entrance to meet Dracula who was played by Gary Oldman, and even Keanu Reeves sleeping in the medieval bed displayed in the museum. It is then without doubt that the Western tourists who blog their travels come to visit Bran Castle with a cultural baggage. As one blogger affirms: "We all know about the $20^{\text {th }}$ century vampire" (19), an assertion supported by a picture of Bela Lugosi wearing a black cape in his role as Count Dracula. But it is not only the Dracula actors that became part of the Western culture, but also the soundtracks of their movies. Voices and music from Dracula movies were used in two blogs as the background for Bran Castle video and pictures.

\subsection{Beliefs and feelings about Dracula}

Western tourists who have blogged about their experiences at Bran Castle seem to know exactly what Dracula represents, how he acts and sounds like. Their depiction of Dracula is represented by feelings of fear: "the name strikes fear into the hearts of millions" (3), "as we hiked the small road up to the castle and entered it, my fears were realized" (3), "you might see some torched welding villages" (16), "a secret passage....it's dark and scary!" (16), "the countryside in Transylvania was spooky" (1), "creaky floors, secret stairways, dark and short passages - creepy enough" (4). These feelings of fear were well expressed by one tourist looking to connect with Dracula and his land: "the butterflies in my stomach did extra somersaults as I peered longingly up into the darkness of the imposing mountains" (13). It is obvious that the Dracula novels and movies have shaped the Western culture, making people actually feel scared of places associated with Dracula.

Fictional representations of Dracula have also fostered confused images of what Dracula is. Some bloggers refer to Dracula as a magician of some sorts: "the Dracula guy just did like this (hand gesture) and made it (the castle) go up by magic!" (15). Other view him not just as a vampire but as a cannibal, a man eater: "Here is a room where Dracula ... [inaudible] his guests before eating them alive" (16). Others view Dracula as a shape-changer, especially in the iconic representation of a bat: "It is actually called a bat window because this is where Dracula would take a ... (inaudible)...he would 
jump out the window and turn into a bat!" (16). The data suggest that Western tourists have definite if confused ideas of what Dracula symbolizes. In their minds, Dracula is the pure image of evil, a vampire that drinks human blood and a magical being who brings fear into the hearts of people.

\subsection{Imitating Dracula}

However scary he might seem, the attraction to Dracula is incontestable. Tourists' encounter with Dracula's fictional residence allows them to express their fascination with the character by imitating him. The bloggers' reproduction of Dracula is present either by them posing with fangs, black capes, or by making scary faces and sounds. The video blogs reveal Western tourists speaking with an accent: "Whohoho!! I can smell his blood!" (16), "Whohohwhowho! What are you doing in my mansion, you infidels?" (15), "You see, they're thinking I am filming the castle, but no! I am filming them instead [camera focusing on women]. Yes, yes!! You will all be my victims tonight!!" (15). One blogger chose to wear a cape: "I decided to wear my Dracula cape. I am going to sneak up on them and scare them!!" (15), while three other enthusiasts pose with Dracula teeth, one by posting a picture of himself holding his fingers as fangs, and two other tourists using plastic fangs: "Jessica and Daniella bought some AWESOME Dracula teeth and had fun posing around the castle" (10). In their search for the sensational, bloggers choose to imitate Dracula by posing or speaking like him. Of course, these images are representations of what they learned from Dracula novels and movies, making them believe they know exactly who Dracula is. However, when they travel to Bran in search for him, some tourists remain profoundly disappointed with what they find.

\section{All I could find was Draculaville...}

The third and last theme, All I could find was Draculaville..., encompasses those images of Western bloggers' dissapointment in not finding Dracula in Bran but a world of Dracula souvenirs and merchandise instead. The theme has two sub-themes: Tourists' disappointment, and Local promotion of Dracula.

\subsection{Tourists' disappointment}

Travelling to Transylvania in search of Dracula carrying the Draculian culture in their backpacks, some Western bloggers find themselves disappointed with what they find, or more precisely, with what they don't find. Many bloggers expressed their dissatisfaction with Bran Castle: "Took a bus out to Bran Castle, aka Dracula's Castle, and were thoroughly under whelmed... The museum inside does not even mention Dracula" (1), "Incredible that this small, scrawny wimp of a castle could be the home of the only person who gave me nightmares as a kid...we made our way through the rest of the rather dry and boring castle" (3), "But the payoff if it [the castle] being about Dracula didn't meet the expectations" (5), "Unfortunately... Dracula never lived in Dracula's Castle. It was very disappointing" (10). Tourists do not only expect the castle to embody Dracula, but also the people working in Bran: "we were rather disappointed to discover the staff didn't have long black cloaks, dodgy greased black hair and long pointy teeth!" (14). Whether they expected to find Dracula alive at Bran Castle, or tour guides working the part, some Western bloggers seemed to have missed the historical beauty of the castle while focusing so much on finding Dracula. By the end of their trip, they realized that the only Dracula they would find was the one painted on souvenirs.

\subsection{Local promotion of Dracula}

The image of Bran as Dracula-central is well portrayed by one blogger in particular:

When we got to the town of Bran, we found Tourist Central. Cars, people, and souvenir vendors, chaos, a real madhouse... About 14 million other people were on the same path and things were not looking very good for a pleasant visit... When we got to the top we found a long line for tickets...we came back down, saw the line was only worse...

The town of Bran, aka Draculaville. Crazy! There was vampire-themed tourist kitsch for sale everywhere and people were buying it! Vampire t-shirts, Vampire wine, Dracula vodka, mugs, plaques, you name it (9) 
Tourists express their disbelief of how the locals responded to tourist demands for Dracula: "You can buy all sorts of fangs, bloody and batty paraphernalia at most of the several dozen kitscheries just below the castle, or you can stay at Vampire Camping" (1), "we walked through the sea of Dracula merchants" (3), "the various hawkers were selling mugs and teeshirts and masks all with the hyperbolic visage of Vlad Tepes, the original Count Dracula" (7). Bloggers posted video and pictures of Dracula mugs and t-shirts, scary masks, Dracula vodka and wine, and other merchandise. It is without question that this image of Bran is a result of the sea of tourists searching for Dracula.

While not being able to find Dracula inside Bran Castle, some tourists opted for purchasing or consuming any Dracula goods: "it was very disappointing...but we did get some cool tshirts" (10), "we sat in a small restaurant for a chat over a bottle of "Vampyre"' (13), "we were supposed to stay at Count Dracula hotel" (19), "Arriving at Vampire Camping in Bran" (14). If Western tourists cannot find Dracula alive and well in his castle, they look for him in other places...

\section{B. Perceptions of tour guides}

The analysis of interviews resulted in four themes illustrating the tour guides' experiences with Dracula tourism: World-renowned attraction, Who is the tourist?, Balancing history with myth, and Dracula's future. Due to confidentiality issues, the three guides are identified as Guide 1, 2 and 3.

\section{World-renowned attraction}

Characterized by notions of fame, the theme World-renowned attraction includes images of tourist groups coming from all over the world to see Bran Castle. The tour guides consider Bran Castle the most important attraction in Romania, the main reason why tourists come to visit Bran, an attraction made famous by the myth of Dracula. Guide 1 believes Bran Castle to be "the most important historical structure in our country but also over the borders"; while Guide 2 reinforces this idea by stating that "the main attraction for tourists coming to Romania represents Bran Castle".

The fame of Bran Castle is exemplified by the numbers of tourists visiting each year: "On the footsteps of Count Dracula are tens, hundreds of thousands of tourists" (Guide 2), "during the summer, 3000 tourists every day" (Guide 3). Tourists come to Bran Castle in "organized groups" (Guide 1) brought by tourism agencies who have contracts with Bran Castle: "So, we work primarily with tourism agencies" (Guide $3)$, agencies that "have contracts with the ones in foreign countries, and in their tours they include Bran Castle also" (Guide 1). The number of tourists visiting the castle each year is not the only proof of its fame, but the fact that these tourists come from all over the world also shows how well known Dracula is. Guide 1 describes the tourists visiting Bran Castle:

Their curiosity and wish to see the Castle associated with the famous and feared Count Dracula comes from all cultures in the world: Europe, United Sates, from the far Asia, the Islamic states, etc...there is no specific nation. They even come from the furthest corners of the world and in different seasons. In August the Italians, JuneJuly the Americans, in September the Hungarians are coming, and in the fall months there are many people from Israel.

Although the Dracula myth is the creation of a Western writer, the myth has reached all nations, attracting people "from all over the world" (Guide 2). Dracula's fame has become so imprinted into peoples' culture that it is now considered a brand. Bran Castle was once a simple medieval castle; however, it is now "a tourist attraction becoming a brand" (Guide 1). Guide 2 believes Dracula is a brand "because in every corner of the world, if you say: Dracula, they know Romania". The name of Dracula identifies the destination, attracting tourists from all over the world, while bringing benefits to the locals who "are dependent on this brand" (Guide 2). Visitors "come back year after year" (Guide 3), their "frequent return" 
(Guide 3) being a result of a continuous interest in this world renowned brand.

\section{Who is the tourist?}

The duality of Dracula's image resulted in the Who is the tourist? theme, represented by two groups of visitors: those interested in the history of the castle and Vlad Tepes, and those in search for Dracula, the vampire. Guide 3 talks about the Dracula enthusiasts who visit Bran Castle: "Because of the talented Irish writer, Bram Stoker, the author of the novel Dracula, millions of people created in their mind a unique phenomenon, a phenomenon which they would wish to live in the places related to Dracula." These tourists "come to Transylvania in search for the character" (Guide 2), bringing with them a baggage full of expectations based on their image of what Dracula represents: "they believe there are torture rooms, coffins" (Guide 1); "they expect blood on the walls, vampire clothing, and all kind of surprises on the tour" (Guide 2).

When asked specifically about Western tourists, Guide 1 explains their expectations:

The Western tourists do not expect to find the pure Romanian medieval history, but a castle full of stories and legends about the count, they expect to find the count's house with all its grim and scary surprises such as: the coffin where the count was resting his hundreds of years old bones, the rooms with the girls who kept him company during the full moon nights when transforming in bats were flying to find the next victims, how the legend says.

If Dracula-seekers expect to see a vampire's home, while demanding to find scary images, they are also afraid of what they might encounter. Dracula as a source of fear penetrated the minds of people from many cultures: "I had a group of Italians, and strong lightning came, they got scared because the electricity went off, and they ran from the room. I tried to tell them it is ok, but they ran and we were only on the first floor of the tour" (Guide 2 ). This quote demonstrates how strongly this group of tourists believed in the Dracula myth.
Guide 2 mentions that these kind of expectations and images in the tourists' mind belong to a world of fantasy: "They have behaviour like they live in a fantasy world...they are sometimes disappointed by the historical barriers that limit their demand of sensational, of cruelty that most of them wish for". Because of the lack of scary things and Dracula-related images, "there are many who leave disappointed" (Guide 1).

However, there are also tourists who visit Bran Castle solely for its historical significance: "there are many who ask me not to tell them anything on the subject because they are not a child, they know how to separate the character" (Guide 2). Guide 1 notes that when giving a tour to these tourists, she feels completely comfortable about presenting the historical facts: "even if I tell them the truth, they don't care about Dracula". The history seekers appreciate Bran Castle for its historical value and are interested in the Romanian history. Guide 3 explains her experience with this type of tourists:

we showed them our history and they left profoundly impressed that they found out about Queen Maria, Princess Ileana, and they saw the castle in its true value, and as a geographical location, and then, automatically, if they did not see Dracula they really liked it and that is why they come back.

Although some visitors are attracted to the historical reality and the beauty of the region, "to compare...there are a lot less than those who want the myth" (Guide 2).

Each group has its own characteristics, each one looking for different things. Their experiences are shaped by the tour guides, however, "those who believe in the myth leave with a sour taste, but those who know history and want to see a historical edifice leave with a good impression" (Guide 1).

\section{Balancing history with myth}

In hopes to satisfy both groups, the tour guides attempt to answer to tourists' demands by Balancing history with myth. To cater to tourists' needs and to present the castle in its 
true light, the guides feel that the best way to inform is by combining historical facts with myth. Guide 1 feels personally responsible for how Romanian history is recounted: "as local guides, we are morally obligated (because nobody ever verifies us) to refer more to history and we don't change it, we tell the truth". However, because "there are curious people who ask what the connection is" (Guide 1), Guide 3 notes that:

even if we do not have specific Dracularelated exhibits at Castle Bran, we tried to combine history with business, the historical truth and legend and we answered well to this demand... The truth does not have to be hidden, and the thirst for the sensational should not be rejected.

The connection between history and myth is done by presenting historical facts, and at the end of the tour, explaining how Dracula and Bran Castle are associated with the fictional vampire. Guide 3 explains how she deals with the tourists' demand:

\begin{abstract}
After we present a succinct history, in order to connect to Dracula.... we make the connection with Bram Stoker and we tell them that none of the books make a specific connection to Bran but because Bran Castle looks a lot like the one in books and because it is from that specific time period, then the association is perfect...
\end{abstract}

Moreover, to satisfy the tourists' thirst for sensational stories, the tour guides focus on historical legends rather than on vampire myths:

For other groups that want jokes and legends, we tell them legends. We have in the area the street called The Row of Thieves, and we tell them that Vlad impaled thieves in a row and now it's named like that. We also tell them the legend about the money bag that was left in the middle of the road but because everyone was afraid of Tepes nobody picked it up. In no way we tell them vampire legends. (Guide 1)

The absence of Dracula-related exhibits inside the museum reinforces the distinction between history and myth: "The Castle does not have arrangements to deal with this theme...Bran Castle Museum does not promote this subject" (Guide 2). Not only there are no Dracula or Vlad Tepes rooms, the museum also does not promote the idea that the castle is Dracula's home. If tourists expected to find a multitude of Dracula promotional material, the castle has "only some postcards with different images of the castle, only one book that tries to explain the historical truth" (Guide 1). This one book, published by the museum and called "Draculamyth and historical reality", was created "to make clear the confusion between myth and reality about over 600 years of history, to stabilize their (tourists) limits and tolerance" (Guide 2). To the guides, telling the historical truth is essential, but so is the need to keep tourists coming back year after year:

With perseverance and imagination, with history and legend, we try to answer to this demand...If we were trying to change the history; this is not good for us as a society... that is why we tried to go along with history without changing it (Guide 3)

\section{Dracula's future}

Lastly, the theme Dracula's future represents the uncertain future of Bran Castle as a private attraction, a future that could be shaped by Dracula enthusiasts. When asked about what the future holds for Dracula tourism, the guides all sounded hopeful, expressing their thoughts that "the future sounds promising" (Guide 2). This hope is due to the new changes in ownership, the castle being restituted to Archduke Dominic von Habsburg of Austria, the son of Princess lleana of Romania. Guide 1 explains the new changes:

The castle was restituted and is now owned by the lawful owner, a member of the Romanian Regal family. The furniture pieces that belonged to the 
Romanian state were collected. Next the owner has to refurnish, to redecorate the castle rooms.

While the redecoration plans are not known yet, the tour guides believe that the new owner will include "something connected to Vlad Tepes, Queen Maria, and Middle Ages. Possibly something Dracula too but I cannot say for sure. Probably there will be a room that will answer the tourists' questions to remind about Vlad Tepes - as historical character for sure, but as myth I cannot tell you" (Guide 3). The uncertainty of the future plans were made known after May $18^{\text {th }}, 2009$ : "these plans will be created after May 18, 2009" (Guide 1), "starting from May 18, 2009, a new chapter in Bran's history will start" (Guide 2).

No matter what the new plans entail, the tour guides believe it will be for the best: "The transition from the national to private domain makes tourism agencies very hopeful, who expect a better promotion and therefore a larger number of tourists" (Guide 2). Guide 2 explains how she thinks the private owner will take charge of the castle:

His interest is to invest more than the state, he will exploit it differently. There will be all kind of beautiful theatre programs every Saturday, birthday parties inside. I think there will be something about the myth too. The interest is to make money, but the owner is an archduke who is part of the history... but the tourists have demands too...things will be better.

Once again, Dracula tourism is facing the conflict between history and myth. While the Archduke Dominic of Habsburg represents the historical past of Bran Castle, Guide 2 believes that his future plans will probably have to take into consideration the demands of Dracula enthusiasts if he wants to keep the tourists coming to Bran Castle.

\section{Discussion}

$R Q$ 1: What are the Western images associated with Dracula tourism?
The image of a destination is produced by the totality of beliefs and impressions people have about the destination, the overall image representing the associations and information about the place (Kotler and Gertner, 2004). The Western images of Dracula and Bran Castle are represented by both fictional and historical elements.

The stimulus factors identified by Baloglu and McCleary (1999) and Govers, Go and Kumar (2007) as image creation agents are represented here by the vampire movies and novels and the tour guides working at Bran Castle. As illustrated in the theme I Know who Dracula is! the vampire culture imposed certain beliefs and impressions on tourists' minds, influencing them to associate Transylvania and Bran Castle with Count Dracula the vampire. At the destination, Western tourists embody the fictional character by imitating him but also by expressing feelings of fear and confusion which often result in disappointment. However, Govers, Go and Kumar (2007) note "tourists will adjust their perceptions of place if what was experienced in consuming the tourism product did not correspond to their perceived destination image..."(p. 17). The historical and local reality images depicted in the themes Reality and Tourists' disappointment allows Dracula enthusiasts to adjust those fictional images. The information provided by the tour guides and the historical reality of the castle influence tourists to form images of Vlad Tepes and Bran Castle as medieval elements, and of Transylvania and Bran as beautiful natural environments.

But not all tourists need to adjust their image of Dracula, as some visit Bran Castle for its historical value as illustrated in the theme Who is the tourist? Hence, tourists' perception of what is real or authentic varies. Smith (1990) notes that in tourism, the concept of authenticity is based on the experiences desired by the tourists and the benefits they associate with the destination. While the Draculian enthusiasts apply their interpretation of what Dracula represents by performing different acts that allows them to fulfill their expectations, the history seekers' perception of reality is based on the historical characteristics 
of the castle and the historical information provided by the tour guides.

In relation to the framework developed by Echtner and Ritchie (1991), the Western image of Dracula encompasses all three sets. The Western images of Dracula are composed of personal perceptions of Dracula but also the historical impression of Bran Castle. These images represent the observable historical castle and the less tangible legends and myths, but also the common and unique elements ranging from a regular tourist attraction to a vampire destination. As Echtner and Ritchie (1991) noted, these elements are always interacting and influencing the other attributes, allowing Dracula's image to be based on a vampire's myth but also on historical elements.

Nevertheless, the tour guides note that the majority of Western tourists who visit Bran Castle are searching for Count Dracula and are often disappointed with the historical reality promoted. The gap between what tourists expect and what is being promoted is identified by Govers, Go and Kumar (2007) as the 3TDS. The following section discusses how Dracula tourism is being promoted at Bran Castle, and how the tour guides' address this gap.

$R Q$ 2: What Dracula images are being promoted at Bran Castle?

Tour guides play an important role in the creation of the destination image and in conveying a sense of authenticity of a destination because they can influence the way people experience and think about the destination (Reisinger and Steiner, 2006). The tour guides represent the organic agents based on Gunn's (1993) classification of image formation agents, being the most credible source of information for tourists visiting Bran Castle.

The guides are the stimulus factors responsible for controlling the amount and type of information given about the destination. Baloglu and McCleary (1999) note that the image of a destination is shaped not only by such information but also by the way it is distributed. As shown in the theme Balancing history with myth, the tour guides provide only historical information on their tours, trying to satisfy the tourists' curiosity and demands for vampiristic myths with historical facts and local legends. Based on the tour guides' effect on the tourists' view of the destination, those visiting can either leave disappointed or impressed with what they found out, feelings illustrated in the themes All I Could Find Was Draculaville..., and Who is the tourist?

Seen through Echtner and Ritchie's (1991) framework, the way Dracula and Bran Castle are presented by the tour guides influences the attribute-holistic set of the destination image, leaving Western tourists with historical images of the destination. Due to the functional elements of the destination, such as the observable historical exhibitions, tourists take in the historical reality of Bran Castle, realizing the Dracula has no connection to the castle. The tour guides' efforts to promote the historical reality are reflected by the Reality theme where Western bloggers describe their impressions of Bran Castle either through text or pictures depicting the objective authenticity.

A destination is authentic when it is simple and disassociated from the current modern society and its demands (White, 2007). The historical nature of Bran Castle and the information provided by the tour guides do not respond to the tourists' demands of what White calls the "otherness". Rather, the tour guides ensure that the historical culture is preserved by trying to eliminate the fictional vampire images associated with the destination. In regards to the perceived authenticity of the place, those who guard the destination might have different views of authenticity based on their goals (Fawcett and Cormack, 2001). If the Romanian government, and therefore the tour guides, did not want to distort the historical truth to gain profit, the new private owner of the castle, Archduke Dominic of Habsburg's view of what is authentic could be driven by an invested economic profit in this world renowned attraction.

\section{Conclusion and future research}

The main goal of this study was to examine the different Western images related to Dracula 
tourism in Transylvania, and to explore the Bran Castle tour guides' role in the formation of the destination image. The findings show that while the majority of Western tourists visit Bran in search for Count Dracula, most of them leave disappointed because the Bran Castle tour guides focus only on presenting the historical truth. Both groups are represented by different agents that manipulate their image of Dracula and Bran Castle. The tourists' image of the destination is influenced by personal factors such as motivation and values, but also by stimulus factors such as the Western pop culture. Cultural influences can include media, movies, novels, childhood experiences, and so forth. The tour guides' image of Dracula is also based on their culture, what they learned from their peers, but also on stimulus factors such as the government.

The study has also presented destination image in connection with the concept of authenticity. Mythical tourism sites cannot be characterized solely by the historical or objectivist theory of authenticity, but also by the tourists' perception of authenticity. The combination of historical facts and tourist experiences allows the concept of authenticity to become a mixed notion, which in turn gives researchers the chance to be more flexible when analyzing tourism sites. By being open to different interpretations, in this case a modern view of authenticity, researchers and tourists can have a more comprehensive understanding of how the concept of authenticity can be applied to a tourism site. This is reflected in the Bran Castle tour guides' explanation of how they bridge history with myth in order to satisfy both ends of the authenticity spectrum.

As for future research, because a destination's global image is based on the amalgamation of tourists' perceptions and impressions who visit from all over the world, researching other cultural groups could yield additional images. This could be done by analyzing blogs written by tourists from Asia, Europe or South America. Another alternative is to conduct research on-site and interview all foreign tourists visiting the castle regardless of their nationality. The data gathered would be based on the perceptions and impressions of tourists from all over the world, therefore allowing the researcher to describe the global image of Dracula.

Moreover, talking to more experts would allow for a better understanding about planning and decision making in regards to Dracula tourism. City hall employees, private tour guides and even hostel and shop owners could be interviewed about their experiences and involvement with Dracula tourism. The local tourism board could provide insight into how they respond to the foreign tourists' demands when developing new plans. The souvenir vendors could offer valuable information about their interaction with Dracula enthusiasts, but also about how they use the myth to their advantage.

Lastly, due to the future changes taking place at Bran Castle, Dracula's image as a tourist destination could face many modifications. Because the data used in this study were gathered in spring 2009, the information offered by the Bran Castle tour guides is based on the government's plans and promotion of Dracula tourism. As the guides noted, the new private owner has unknown business plans which could ensure the sustainability of the castle as a main attraction in Europe. Future studies are necessary in order to examine how the new plans respond to the tourists' demands and expectations, and if and how it affects the global image of Dracula.

\section{References}

Baloglu, S., and McCleary K.W. (1999) A model of destination image formation. Annals of Tourism Research, 26(4), pp. 868 - 897.

Canton, K. and Santos C.A. (2008) Closing the hermeneutic circle? Photographic encounters with the other. Annals of Tourism Research, 35(1), pp. 7-26.

Charmaz, K. (2006). Constructing grounded theory: A practical guide through qualitative analysis. Thousand Oaks, CA: Sage .

Choi, S., Lehto, X.Y., and Morrison, A.M. (2007) Destination image representation on the web: Content 
analysis of Macau travel related websites. Tourism Management, 28(1), pp. 118-129.

Cohen, E. (1988) Authenticity and commoditization in tourism. Annals of Tourism Research, 15(3), pp. 371-386.

Creswell, J.W (2003) Research design qualitative, quantitative and mixed methods approaches. (2nd ed.). London: Sage.

Daly, K.J. (2007) Qualitative methods for family studies and human development. Los Angeles, CA: Sage.

Dan, S. (2009) Brasov: Castelul Bran intra maine in posesia familiei de Habsburg. Adevarul URL: http://www.adevarul.ro/articole/brasovcastelul-bran-intra-maine-in-posesiafamiliei-de-habsburg.html (Accessed on 10.06.2009)

Denzin, N.K and Lincoln, Y.S. (2005) Handbook of qualitative research $\left(3^{\text {rd }}\right.$ ed.) Thousand Oaks, CA: Sage.

Echtner, C.M, and Ritchie, J.R.B (1991) The meaning and measurement of destination image. The Journal of Tourism Studies, 2(2), pp. 2-12.

Edensor, T. (2001). Performing tourism, staging tourism: (re)producing tourist space and practice. Tourist Studies, 1(1), pp. $59-81$.

Fakeye, P.C. and Crompton, J.L. (1991). Image differences between prospective, firsttime, and repeat visitors to the Lower Rio Grande Valley. Journal of Travel Research, 30(10), pp.10 - 16.

Fawcett, C. and Cormack, P. (2001) Guarding authenticity at literary tourism sites. Annals of Tourism Research, 28(3), pp. 686-704.

Fields, E.E. (1988) Qualitative content analysis of television news: systematic techniques. Qualitative Sociology, 11(3), pp. 183-193.

Gartner, W. (1993) Image formation process. Journal of Travel and Tourism Marketing, 2(2/3), pp. 191-215.

Govers, R., F. M. Go and K. Kumar (2007). Promoting Tourism Destination Image. Journal of Travel Research, 46(1), pp. 15-23.
Gunn, C. (1988) Vacationscape: designing tourists regions. New York: Van Nostrand Reinhold.

Herbert, D. (1996). Artistic and literary places in France as tourist attractions. Tourism Management, 17 (2), pp. 77-85.

Herbert, D. (2001). Literary places, tourism and the heritage experience. Annals of Tourism Research, 28(2), pp. 312-333.

Hesse-Biber, S. and Leavy, P. (2006) The practice of qualitative research. Thousand Oaks, CA: Sage.

Holtorf, C; and Schadla-Hall, T. (1999) Age as artefact: on archaeological authenticity. European Journal of Archaeology, 2(2), pp. $229-247$.

Iordanova, D. (2007) Cashing in on Dracula: Eastern Europe's hard sells. Framework: The Journal of Cinema and Media, 48(1), pp. 46-63.

Jamal, T. and Tanase, A. (2005) Impact and conflicts surrounding Dracula Park, Romania: the role of sustainable tourism principles. Journal of Sustainable Tourism, 13(5), pp. $440-$ 455.

Kavaratzis, M. and Ashworth, G.J. (2005) City branding: an effective assertion of identity or a transitory marketing trick? Tijdschrift voor Economische en Sociale Gegrafie, 96(5), pp. 506- 514

Keren, M. (2004) Blogging and the politics of melancholy. Canadian Journal of Communication, 29(1), pp. 5 - 23.

Kotler, P and Gertner, D (2004). Country as brand, product and beyond: a place marketing and brand management perspective. In Morgan, N., Pritchard, A. and Pride, R. (2002). Destination Branding: Creating the unique destination proposition. Burlington, MA: Elsevier.

Krippendorff, K. (2004) Content Analysis: An Introduction to Its Methodology ( $2^{\text {nd }}$ ed.) Thousand Oaks, CA: Sage.

Light, D. (2007) Dracula tourism in Romania. Cultural identity and the state. Annals of Tourism Research, 34(3), pp. 746765.

MacCannell, D. (1973) Staged authenticity: arrangements of social space in tourist 
settings. American Journal of Sociology, 79(3), pp. $589-603$.

MacCannell, D. (1976) The Tourist, a New Theory of the Leisure Class. New York: Shocken.

Muresan, A; and Smith, K.A. (1998) Dracula's castle in Transylvania: Conflicting heritage marketing strategies. International Journal of Heritage Studies, 4(2), pp. 73-85

National Institute of Statistics (2007). Romanian Tourism in Figures. Retrieved from http://www.insse.ro/cms/rw/pages/turis m_rom.ro

Newman, M. and Bristow, R. (2004) Myth vs fact: an exploration of fright tourism. Proceedings of the 2004 Northeastern Recreation Research Symposium.

Pan, B., MacLaurin, T. and Crotts, J.C. (2007) Travel blogs and the implications for destination marketing. Journal of Travel Research, 46(1), pp. 35-46.

Patton, M. Q. (2002) Qualitative Research and Evaluation Methods ( $3^{\text {rd }}$ ed) London: Sage

Pearce, P.L.; and Moscardo, G.M. (1986) The concept of authenticity in tourist experiences. Journal of Sociology, 22(1), pp. 121-132.

Pine, J. and Gilmore, J. (2008) Keep it real. Learning to understand, manage, and excel at rendering authenticity. Marketing Management, 17(1), pp. 1824.

Reisinger, Y., C., and Steiner, J. (2006) Reconceptualizing object authenticity. Annals of Tourism Research, 33(1), pp. 65-86.
Ronay, G. (1972) The Dracula Myth. London: Howard \& Wyndham

San Martin, H. and del Bosque, I.A. (2008) Exploring the cognitive-affective nature of destination image and the role of psychological factors in its formation. Tourism Management. 29(2), pp. 263 277.

Schmallegger, D. and Carson, D. (2007) Blogs in tourism: Changing approaches to information exchange. Journal of Vacation Marketing. 14(2), pp. 99-110.

Shields, L. and King, S. (2001) Qualitative analysis of the care of children in hospital in four countries - Part 1. Journal of Pediatric Nursing, 16(2), pp. 137-145.

Smith, S (1990) Dictionary of concepts in recreation and leisure studies. Westport, CT: Greenwood

Squire, S. (1994). The cultural values of literary tourism. Annals of Tourism Research, 21(1), pp. 103-120.

Squire, S. (1996). Literary tourism and sustainable tourism: Promoting 'Anne of Green Gables' in Prince Edward Island. Journal of Sustainable Tourism, 4(3), pp. 119-134.

Taylor, J.P. (2001) Authenticity and sincerity in tourism. Annals of Tourism Research, 28(1), pp. 7-26

White, C.M. (2007) More authentic than thou. Authenticity and othering in Fiji tourism discourse. Tourist Studies, 7(1), pp. 2549. 